\title{
Yurisdiksi Kelompok Pemberontak Pra dan Pasca Pengakuan Sebagai Subjek Hukum Internasional
}

\author{
Akbar Chusnein*; Akbar Kurnia Putra \\ Fakultas Hukum Universitas Jambi \\ *Corresponding Author : ineinac@gmail.com \\ Submission : 19 Januari 2021 \\ Revision : 18 Mei 2021 \\ Publication : 2 Juni 2021
}

\begin{abstract}
This research aims to provide a general understanding of the jurisdiction for rebel groups before and after their recognition as belligerents, or the shift of the groups in question from domestic legal subjects to legal subjects of the international law. The type of method used in this research is in the form of normative legal research, which utilizes the collection of legal materials relevant to the object of research in the form of literature; The materials referred to are such as: (a) Primary legal materials: The Charter of United Nation, The Geneva Convention, The Hague Convention; (b) Secondary legal materials: legal science books, legal science journals, legal research reports, scientific articles, seminar materials, workshops, and so on; (c) Tertiary legal materials: Legal materials which precepts or provides an explanation on the primary and secondary legal materials, such as legal dictionaries, newspapers, the internet and so on.
\end{abstract}

Keywords: Belligerent; Jurisdiction; Rebels.

\begin{abstract}
Abstrak
Penelitian ini bertujuan untuk memberikan pengetahuan dan pemahaman secara umum mengenai yurisdiksi bagi kelompokkelompok pemberontak pra dan pasca diakuinya peran kelompok tersebut sebagai Belligerent, atau beralihnya kelompok-kelompok yang dimaksud dari subjek hukum domestik menjadi subjek hukum
\end{abstract}


dari hukum internasional. Tipe penelitian yang digunakan sendiri adalah berupa penelitian hukum normatif, yang memanfaatkan pengumpulan bahan-bahan hukum yang relevan dengan objek penelitian dalam bentuk kepustakaan; Bahan-bahan yang dimaksud adalah seperti: (a) Bahan hukum primer: The Charter of United Nation, The Geneva Convention, The Hague Convention; (b) Bahan hukum sekunder: Buku-buku ilmu hukum, jurnal ilmu hukum, laporan penelitian ilmu hukum, artikel ilmiah, bahan seminar, lokakarya, dan sebagainya; (c) Bahan hukum tersier: Bahan hukum yang memberikan petunjuk maupun penjelasan terhadap bahan hukum primer dan sekunder, seperti kamus hukum, surat kabar, internet dan sebagainya.

Kata Kunci: Belligerent; Pemberontak; Yursidiksi.

\section{A. Pendahuluan}

Hukum internasional sebagaimana diketahui bentuk dan implementasinya saat ini merupakan produk sejarah masyarakat internasional dalam usaha menciptakan lingkungan hidup yang damai dan saling menunjang bagi satu sama lain. Masyarakat internasional secara bersama melahirkan suatu hukum, baik itu melalui perjanjian, kebiasaan ataupun prinsip-prinsip umum yang ada; yang mana hukum tersebut secara sengaja ataupun tidak sengaja, dibentuk sedemikian rupa sehingga sifatnya mempromosikan keadilan dan kepentingan bersama, dan keberadaannya tidak bertentangan dengan suatu kedaulatan bagi mereka yang terlibat di dalamnya.

Layaknya hukum nasional ataupun sistem hukum lainnya, hukum internasional juga memiliki subjeknya sendiri, yaitu entitas dengan kemampuan untuk memegang hak-hak 
dan kewajiban hukum dalam skala internasional; Yang mana dengan seiring berjalannya waktu, entitas-entitas tersebut kemudian kian bertambah, dan definisinya pun meluas, mengikuti berkembangnya kebutuhan dan keberadaan dari hukum internasional Sehingga kini esensinya tidak terpaku hanya pada negara saja, selaku subjek hukum internasional yang tunggal.

Beberapa subjek hukum internasional yang pada umumnya telah kerap diakui diantara lain: ${ }^{1}$

1. Negara;

2. Organisasi Internasional;

3. Palang Merah Internasional;

4. Tahta Suci atau Vatikan;

5. Perusahaan;

6. Pihak berperang;

7. Individu.

Satu hal yang konstan dalam aspek penentuan subjek hukum internasional merupakan keberadaan spektrum kapasitas pada masing-masing entitas, yang menjadikannya dianggap sebagai subjek hukum internasional; Yaitu kapasitas yang merumuskan masing-masing darinya untuk mampu terlibat dengan hukum terkait lintas batas negara. Karakteristik ini lah yang merujuk pada legal capacity atau juridical capacity dan kemudian mengarah pada legal personality atau juridical personality yang dimiliki oleh setiap subjek hukum internasional.

1 Wayan Parthiana. Pengantar Hukum Internasional. Cet. 2. Bandung. Mandar Maju. 2003, hal. 59. 
"The terms international legal personality and international legal capacity describe the same characteristic, namely the fact that an entity is capable of possessing international rights and duties." ${ }^{2}$

Karena yang dimaksud dengan subjek hukum internasional merupakan entitas yang mampu memiliki hak dan kewajiban internasional, maka legal personality dan international legal capacity menjadi patok dalam menentukan siapa-siapa saja yang dapat disebut sebagai subjek hukum internasional.

Berdasarkan kedua konsep di atas, suatu entitas haruslah memenuhi kualitas minimum tertentu untuk dapat menikmati keuntungan dari hak-hak yang diberikan oleh hukum tersebut atau harus memiliki kewajiban tertentu untuk melakukan kegiatan yang berkaitan dengan hukum; Entitas yang telah memenuhi kualifikasi minimum tersebut lah yang dapat dikatakan telah memiliki juridical personality. ${ }^{3}$ dan personalitas ini menentukan kedudukannya di dalam suatu sistem hukum.

Lalu yang menjadi pertanyaan adalah apabila di dalam suatu negara, terdapat suatu komunitas yang ingin merepresentasikan dirinya sendiri di muka masyarakat internasional, dan menyatakan bahwa dirinya memiliki

2 Christian Walter. Subjects of International Law. Encyclopedia of Public International law. Mei 2007. hal. 6.

3 Gerhard von Glahn dan James Larry Taulbee. Law Among Nations: An Introduction to Public International Law. Cet. 10. New York. 2016. hal. 139.

Uti Possidetis: Journal of International Law, Vol. 2, No. 2 (2021) 
kedaulatan yang terpisah (memerdekakan dirinya). Komunitas ini lah yang kemudian dapat dikenal dengan sebutan pemberontak dan kemudian mengarah pada sebutan insurgent dan dalam beberapa kasus sebagai belligerent.

Pada umumnya dapat diterima bahwa Insurgency merujuk pada kebangkitan atau pemberontakan yang dilakukan oleh suatu kelompok yang terorganisir melawan pemerintah atau otoritas pemerintahan; ${ }^{4}$ dan mereka yang melakukan insurgency-lah yang disebut sebagai insurgent; sedangkan Belligerency mengarah pada keadaan di mana kekuatan dari satu atau lebih "negara" melakukan penguasaan yang efektif terhadap suatu wilayah negara lain. ${ }^{5}$

Terlepas dari motif dan sejarah kelompok-kelompok yang menggalangi kedudukan pemberontak selagi menghasilkan kesimpang siuran akan statusnya berupa pemberontak yang diakui sebagai subjek hukum internasional, keberadaannya tentu tidak dapat dipandang sebelah mata, baik itu oleh negara maupun oleh masyarakat-masyarakat internasional lainnya dan kaum akademisi sekalipun; Pasalnya kelompok yang demikian memiliki sifat yang mengancam kesatuan suatu negara, dan berkenaan dengan kedaulatan; Maka dari itu, penting untuk diketahui kejelasan terhadap yurisdiksi dari kelompok-kelompok terkait.

4 Emily Crawford. "Insurgency". Oxford Public International Law, Encyclopedia entries. Juni 2015. hal. 1.

5 Eyal Benvenisti. "Occupation, Belligerent". Oxford Public International Law. Encyclopedia entries. Mei 2009. hal. 1. 


\section{B. Pembahasan}

Istilah pemberontakan, insurgency, dan belligerency sejatinya merujuk pada keadaan tertentu dari suatu proses yang sama; Yaitu proses dalam melawan suatu otoritas tertentu, dan bahkan negara secara menyeluruh. Ketiga konsep ini juga mengarah pada satu isu berupa Perang Sipil atau Civil War, atau lebih dikenal dengan istilah Interstate War dalam cabang ilmu polemologi. ${ }^{6}$ Baik itu kelompok Pemberontak, kelompok Insurgent ataupun kelompok Belligerent, ketiganya bermula, berada, atau melewati suatu proses semacam Perang Sipil - Dalam skala yang lebih kecil, dikaitkan dengan gangguan sipil, atau Civil Disturbance ${ }^{7}$. Perang Sipil sendiri dapat diartikan sebagai:

“...a violent conflict within a country fought by organized groups that aim to take power at the center or in a region, or to change government policies." ${ }^{8}$

Dengan makna yaitu: Suatu konflik atau peperangan di dalam negara yang dilangsungkan oleh kelompok-kelompok terorganisir dengan tujuan untuk mengambil kekuasaan pada

6 Polemologi atau Polemology adalah cabang ilmu pengetahuan yang menganalisis perseteruan manusia dan peperangan, terutama perang dalam skala internasional.

7 Civil Disturbance atau gangguan sipil, merupakan tindakan kekerasan dan ketidak patuhan yang memprejudiskan hukum publik serta ketertiban.

8 James D. Fearon. "Iraq's Civil War". Foreign Affairs. Maret 2007. hal. 1. 
suatu wilayah, atau untuk merubah ketentuan dari pemerintah setempat. Salah satu poin terpenting pada definisi ini adalah penekanan bahwa pada konflik Perang Sipil, yang menjadi salah satu pihak konflik tersebut merupakan Negara atau Pemerintah.

Dalam penelitian yang dilangsungkan oleh penulis, penulis sendiri tidak menemukan terdapatnya definisi hukum secara spesifik yang mengatur tentang Perang Sipil di dalam Konvensi Jenewa dan Protokol I dan II. Meski demikian, suatu Perang Sipil tetap diatur dalam Konvensi Jenewa atas hubungannya dengan konflik bersenjata atau Armed Conflict, terutama konflik bersenjata yang tidak berasal dari "karakter" internasional - Di mana ditemukannya batasan dan lingkup tanggung jawab bagi para pihak. Sebagai contoh, Article 3, Chapter I, Geneva Convention for the Amelioration of the Condition of the Wounded and Sick in Armed Forces in the Field, 12 Agustus 1949.

Hal ini membuktikan bahwa secara tidak langsung setiap pihak yang mengambil peran dalam konflik bersenjata, termasuk Pemberontak, Insurgent dan Belligerent, meskipun tidak atau mungkin belum diakui sebagai subjek hukum internasional, mereka tetap diharuskan untuk tunduk pada aturan-aturan hukum internasional tertentu yang berkaitan dengan segala kegiatan yang mereka lakukan.

Lebih lanjut pada Chapter Idan Article I, Ayat 7, Piagam PBB merumuskan: 
"Nothing contained in the present Charter shall authorize the United Nations to intervene in matters which are essentially within the domestic jurisdiction of any state or shall require the Members to submit such matters to settlement under the present Charter; but this principle shall not prejudice the application of enforcement measures under Chapter VII."9

Bahwa tidak ada ketentuan-ketentuan yang terkandung dalam Piagam ini yang memberi kuasa kepada PBB untuk ikut campur dalam persoalan yang pada hakekatnya merupakan yurisdiksi domestik negara manapun atau yang mewajibkan para Anggota-Anggotanya untuk menyelesaikan persoalan tersebut menurut Piagam ini; akan tetapi prinsip ini tidak mengurangi ketentuan mengenai penggunaan tindakantindakan pemaksaan di bawah Chapter VII.

Penulis juga menemukan bahwa suatu gerakan "Pemberontak" semata, pada prakteknya jatuh pada yurisdiksi dari negara bersangkutan, di mana pemberontakan yang dimaksud berlangsung di wilayah negara tersebut; Hal ini disebabkan sebagai akibat diperlakukannya konflik yang demikian sebagai urusan domestik masing-masing negara oleh hukum internasional. Prinsip ini, meski tidak ditetapkan langsung oleh hukum internasional telah menjadi conde of conducts bagi banyak negara. Hal ini dapat dibuktikan dengan kasus terkait Nicaragua dan Amerika Serikat. Di mana dalam

9 United Nations. Charter of the United Nations. 24 October 1945, 1 UNTS XVI. Dapat diakses melalui: https://treaties.un.org/doc/ Publication/CTC/uncharter.pdf

Uti Possidetis: Journal of International Law, Vol. 2, No. 2 (2021) 
kasus tersebut, Amerika Serikat didapatkan telah memberikan dukungan salah satunya berupa persenjataan kepada suatu kelompok pemberontak di Nicaragua yaitu Contras. ${ }^{10}$

Diadili di hadapan International Court of Justice, kasus Nicaragua vs Amerika Serikat diputuskan dimenangi oleh Nicaragua. Dalam kasus ini, Pengadilan menemukan salah satunya bahwa:

"The right to sovereignty and to political independence possessed by the Republic of Nicaragua, like any other State of the region or of the world, should be fully respected and should not in any way be jeopardized by any military and paramilitary activities which are prohibited by the principles of international law, in particular the principle that States should refrain in their international relations from the threat or use of force against the territorial integrity or the political independence of any State, and the principle concerning the duty not to intervene in matters within the domestic jurisdiction of a State, principles embodied in the United Nations Charter and the Charter of the Organization of American State."11

Atau diterjemahkan ke dalam Bahasa Indonesia menjadi:

Hak untuk berdaulat dan berkemerdekaan politik yang

10 Contras dulunya merupakan kelompok-kelompok pemberontak sayap-kanan yang didanai dan didukung oleh Amerika Serikat dan aktif pada tahun 1979 sampai awal 1990-an menentang Marxist Sandinista Junta of National Reconstruction Government di Nicaragua.

11 International Court of Justice, Military and Paramilitary Activities in and Against Nicaragua (Nicaragua v. United States of America), Merits, Judgment, I.C.J. Reports 1986, hal. 14. Lihat juga: United Nation's, Summaries of Judgments, Advisory Opinions and Orders of The International Court of Justice. 1948-1991. ST/LEG/SER.F/1. New York. 1992. hal. 125-128. 
dimiliki oleh Republik Nicaragua, layaknya negara manapun dari wilayah di dunia, wajib untuk dihormati secara penuh dan wajib untuk tidak dengan cara apapun dibahayakan oleh aktifitas militer dan paramiliter yang mana dilarang oleh prinsip-prinsip hukum internasional, khususnya prinsip bahwa Negara harus menahan diri dalam hubungan internasionalnya dari ancaman atau penggunaan kekerasan melawan integritas teritorial atau kemerdekaan politik suatu Negara, dan prinsip mengenai kewajiban untuk tidak campur tangan $^{12}$ dalam persoalan-persoalan terkait yurisdiksi domestik suatu Negara, prinsip-prinsip yang terkandung dalam Piagam PBB dan Piagam Organisasi Negara Amerika atau (Charter of the Organization of the American States).

Uraian di atas memberikan kita pemahaman bahwa berdasarkan tradisi hukum internasional sendiri, "Pemberontakan" tidak termasuk sebagai bagian dari para pihak dalam Perang Sipil - terlebih menginjak yurisdiksi internasional untuk menjadi Subjek Hukum Internasional; Meski demikian, pemberontakan dalam artian Insurgency dan Belligerency merupakan perang yang dianggap sebagai Perang Sipil, atau bahkan lebih, terutama bagi Belligerent. ${ }^{13}$ Perlu

12 Prinsip ini dikenal dalam Bahasa Inggris dengan sebutan: Principle of Non-intervention.

13 Nadarajah Pushparajah. "The Concept of Civil War in Traditional International Law”. Legal Voice Blog. Artikel, 2 Desember 2016. hal. 1. Dapat diakses melalui: https://legalvoiceblog.wordpress.co $\mathrm{m} / 2016 / 12 / 02 /$ the-concept-of-civil-war-in-traditional-internati onal-law/\# ftn6

Uti Possidetis: Journal of International Law, Vol. 2, No. 2 (2021) 
dicatat bahwa tidak ada satu benua pun yang tidak tersentuh oleh gangguan internal berupa konflik internal bersenjata.

Ketiganya memiliki hak dan kewajiban serta statusnya masing-masing, pertikaian yang dilangsungkan oleh kelompok "Pemberontak", baik itu bersenjata ataupun yang tidak bersenjata hanya merupakan bagian dari Civil Disobedience atau gangguan sipil (Civil Disturbance), dan juga memiliki sifat yang biasanya sporadis atau berumur pendek. ${ }^{14}$ Kapan dan sejauh apakah korban gangguan sipil yang dibutuhkan atau besarnya perseteruan agar konflik tersebut dapat dikatakan setidaknya sebagai Perang Sipil, masih menjadi suatu perdebatan. ${ }^{15}$ Namun tentu tidak dalam skala yang kecil.

Berdasarkan doktrin-doktrin internasional, perbedaan akan ketiganya jika dibandingkan terkait wilayah hukum adalah: Setiap kegiatan Pemberontakan jatuh pada kategori urusan domestik; Begitu pula dengan Insurgency juga merupakan persoalan domestik, tetapi dapat diinternasionalkan melalui ad hoc, sehingga statusnya

14 Ibid. Lihat juga: Anthony Cullen. "Key Developments Affecting the Scope of Internal Armed Conflict in International Humanitarian Law". 2005. Military Law Review. hal. 66-69; Lihat juga: L. Oppenheim, Op. Cit., hal. 162.

15 Beberapa ahli ilmu politik menyatakan suatu Perang Sipil membutuhkan setidaknya 100 korban dari masing-masing pihak. Lihat (untuk contoh): Edward Wong, "A Matter of Definition: What Makes a Civil War, and Who Declares It So?" New York Times, Artikel, 26 November 2006. Dapat diakses melalui: https://www.nytimes.com/2006/11/26/world/middleeast/26w ar.html ; Lihat juga Ann Hironaka, Neverending Wars: The International Community, Weak States, and the Perpetuation of Civil War, Harvard University Press, Cambridge, 2005, hal. 28. 
dikatakan mungkin untuk menjadi Subjek Hukum Internasional - "Mungkin" di sini juga dikarenakan sebahagian pengakuan yang ia miliki; Di sisi lain terdapat Belligerency, di mana Belligerent adalah Subjek Hukum Internasional dalam arti yang penuh. ${ }^{16}$ Hak-hak dan kewajiban internasional secara penuh hanya akan mungkin untuk dimiliki kelompok "pemberontak" apabila suatu gerakan tersebut telah mencapai titik Belligerency yang tidak lagi dipertanyakan.

"There was enough of international law to be able to apply to this different issue. If you're always waiting for an answer on the very specific issue you'll never decide anything. The law is there to apply to new problems."17

- Rosalyn Higgins

\section{Penutup}

Berdasarkan hasil penelitian ini, maka dapat ditarik kesimpulan sebagai berikut: terdapat tiga tahap pemberontakan, yaitu: pemberontakan (rebellion), Insurgency, dan belligerency. Baik itu pemberontakan, insurgency ataupun belligerency, ketiganya dipandang harus tunduk terhadap hukum dan kebiasaan perang. Pemberontakan (rebellion)

16 Richard A. Falk. The International Law of Civil War. Lawbook Exchange Ltd., New Jersey, 30 Maret 2010. hal. 194-199 dan hal. 369-375.

17 Wawancara oleh Catherine Amirfar kepada Dame Rosalyn C. Higgins, mantan Hakim dan Presiden ICJ, Episode 8: The World Court and the Immunity of Int'l Organizations, The Society's Podcast. Dapat diakses melalui: https://www.asil.org/ resources/podcast/ep8 ; Saat itu Rosalyn Higgins merujuk pada suatu permasalahan terkait penggunaan nuklir yang diargumenkan oleh salah satu pihak dalam pengadilan bahwa tidak diatur oleh hukum internasional. 
merupakan gangguan sipil atau civil disorder, yang jatuh pada yurisdiksi domestik. A priori: Pemberontak bukan Subjek Hukum Internasional. Insurgency, merupakan perang sipil atau civil war, yang dalam keadaan tertentu seperti kaitannya secara ad hoc dapat menjadi yurisdiksi hukum internasional. $A$ priori: Insurgent dapat menjadi Subjek Hukum Internasional. Belligerency, tidak hanya terpaku oleh perang sipil, tapi juga dapat diartikan kedalam perang lain, dan ditemukan menjadi yurisdiksi hukum internasional. A priori: Belligerent adalah Subjek Hukum Internasional.

\section{Referensi}

\section{Instrumen Hukum}

Geneva Convention (I) for the Amelioration of the Condition of the Wounded and Sick in Armed Forces in the Field, 1864 (revised in 1949).

Geneva Convention (II) for the Amelioration of the Condition of Wounded, Sick and Shipwrecked Members of Armed Forces at Sea, 1949.

Geneva Convention (III) relative to the Treatment of Prisoners of War, 1929 (revised in 1949).

Geneva Convention (IV)relative to the Protection of Civilian Persons in Time of War, 1949.

ICJ, "Advisory Opinion on Reperation for Injuries Suffered in the Service of the United Nations", ICJ Report, 1949.

ICJ, Military and Paramilitary Activities in and Against Nicaragua (Nicaragua v. United States of America), Merits, Judgment, I.C.J. Reports 1986, hlm. 14. Lihat juga: United Nation's, Summaries of Judgments, Advisory Opinions and Orders of The International Court of Justice, 1948-1991, ST/LEG/SER.F/1, New York, 1992. 
ICRC, "What is International Humanitarian Law," Advisory Service on International Humanitarian Law, Juli 2004.

ICRC, Commentary of 1960 on the Convention (III) relative to the Treatment of Prisoners of War, Geneva, 12 Agustus 1949. Dapat diakses melalui: https://ihldatabases.icrc.org/applic/ihl/ihl.nsf/COM/375-590006

Protocol I relating to the Protection of Victims of International Armed Conflicts, 1977.

Protocol II relating to the Protection of Victims of NonInternational Armed Conflicts, 1977.

Protocol III relating to the Adoption of an Additional Distinctive Emblem, 2005.

Report of the International Law Commission on its Second Session, 5 Juni hingga 29 Juli tahun 1950,Official Records of the General Assembly, Fifth session, Supplement No.12 (A/1316), dokumen: A/CN.4/34.

The Hague Convention, on the Laws of War and War Crimes, 1899 (I-IV, 2).

The Hague convention, on the Laws of War and War Crimes, 1907 (I-XIV).

The Montevideo Convention on the Rights and Duties of States, 1933.

The Treaty of Versailles, World War I's Peace Treaty, 1919.

United Nations Charter, 1945.

\section{Buku}

Falk, Richard A. The International Law of Civil War. Lawbook Exchange Ltd.. New Jersey. 30 Maret 2010.

Glahn, Gerhard von dan James Larry Taulbee. Law Among Nations: An Introduction to Public International Law. Cet. 10. New York. 2016.

Oppenheim, L. International Law. $8^{\text {th }}$ edition. Vol. II. Longmans, Green and Co.. London. 1912. 


\section{Artikel/Jurnal/Karya Imiah}

Benvenisti, Eyal. "Occupation, Belligerent". Oxford Public International Law. Encyclopedia entries. Mei 2009.

Crawford, Emily. "Insurgency". Oxford Public International Law. Encyclopedia entries. Juni 2015.

Cullen, Anthony. "Key Developments Affecting the Scope of Internal Armed Conflict in International Humanitarian Law". Military Law Review. 2005.

Walter, Christian. "Subjects of International Law". Encyclopedia of Public International law. Encyclopedia entries, Mei 2007.

\section{Website}

Edward Wong. "A Matter of Definition: What Makes a Civil War, and Who Declares It So?" New York Times. Artikel. 26 November 2006. https://www.nytimes.com/2006/11 /26/world/middleeast/26war.html, diakses pada tanggal 23 November 2020.

Fearon, James D. "Iraq's Civil War". Foreign Affairs. Maret 2007. http://www.foreignaffairs.org/20070301faessay86 201/ja mes-d-fearon/iraq-s-civil-war.html , diakses pada tanggal 22 November 2020.

Pushparajah, Nadarajah. "The Concept of Civil War in Traditional International Law". Legal Voice Blog. Artikel. 2 Desember 2016. https://legalvoiceblog.wordpress.com /2016/12/02/the-concept-of-civil-war-in-traditional-inter national-law/\# ftn6, diakses pada tanggal 22 November 2020.

Shekhar, Mayank. "Subjects of International Law". Legal Bites. Artikel. 17 September 2016. https://www.legalbites in/subjects-international-law/, diakses pada tanggal 21 November 2020. 